\title{
Fiscal and Monetary Policies and Economic Growth
}

\author{
Moisa Altar \\ Academy of Economic Studies \\ Bucharest
}

This draft : January 2003

Prepared for the European Monetary Union Seminar

European University Institute, Florence 


\begin{abstract}
The paper analyses the way in which monetary and fiscal policy influences the performances of economic growth. The analysis is made on the basis of a dynamic model with discrete variables of the Sidrauski- Brock type, with infinite-lived households and money in the utility function. The model is with a representative private agent and a government sector consisting of a consolidated fiscal authority and central bank. Households receive an exogenous perishable endowment each period, decide about consumption and pay net real lump-sum tax.

The state variable of the model is government debt, and the decision variables are: consumption and the amount of money detained by the agent.

The optimality conditions are obtained by using the Maximum Principle for discrete dynamic systems. A qualitative analysis of the optimal trajectories is performed, on the basis of the information provided by the Maximum Principle, concerning the dynamics of the dual variable and the properties of the Lagrange multipliers.
\end{abstract}

Finally, we analyze the influence of several monetary and fiscal decisions on the optimal trajectories and on the performance-function of the model.

JEL Clasification : C 61, D 99,E 31, E 41, E 62, E 63, H 62, H 63, O 41.

Keywords: Economic Growth, Monetary Policy, Fiscal Policy, Fiscal Solvency, Maximum Principle

Moisa Altar, Doctoral School of Finance and Banking, Academy of Economic Studies, 6 Piata Romana, sect. 1, Bucharest, Romania

e-mail: maltar@ase.ro

maltar@starnet.ro

http://www.dofin.ase.ro 


\section{Contents}

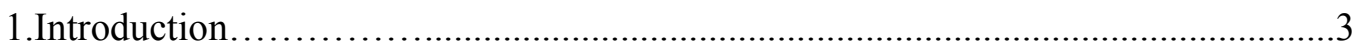

2.The Model...........................................................4

2.1.Household and Government Behavior...............................4

2.2. The Optimization Problem......................................... 7

2.3.Qualitative Analysis of Optimal Trajectories.........................10

2.4. Transversality Conditions.......................................12

2.5. The Case of Bernoulli type Utility Functions........................13

3. Compatibility between Monetary and Fiscal Policy. Fiscal Solvency ..............16

4. Conclusions ............................................................ 19

References...........................................................20 


\section{Introduction}

In recent years relative effectiveness of monetary and fiscal policy action on economic growth has been debated by both economists and policy makers.

The traditional optimal currency areas literature pointed out long ago that, in a monetary union, fiscal policy has to play a more important role in cyclical stabilization given the loss of national monetary independence. This is particularly the case if shocks are not perfectly correlated across frontiers. Fiscal flexibility, together with budgetary discipline and co-ordination, has come to be seen as a central pillar of fiscal policy in a currency area (Commission, 1990). The Stability and Growth Pact (SGP) has been the operational response of EU countries to the quest for budgetary discipline in EMU.

Recent theoretical and empirical developments have shed new light on the 'old' issue of the interaction between monetary and fiscal authorities.

There are numerous studies, both theoretical and empirical, analyzing the relation between inflation and long-run growth.

In the past decade the development of the endogenous growth literature pioneered by Romer (1986), Lucas (1988), and Rebelo (1991) has enhanced our understanding about how an economy's growth performance can be affected by public policies. For instance, Barro (1990) and King and Rebelo (1990) study the effects of fiscal policies, such as government spending and taxation, on economic growth. The general conclusion is that taxation adversely affects long-run growth performance and that the quantitative impacts are much larger than those found in exogenous growth models. Chari, Jones, and Manuelli (1995) and van der Ploeg and Alogoskoufis (1994) examine the effects of monetary policies, such as changes in the growth rates of nominal money supply, on long-run real activity. These authors find support for the conventional wisdom that inflation and long-run growth are inversely related. These studies also represent an advance in our understanding of the impact of alternative policies on inflation and growth.

Recently economists have been paying increasing attention to a dynamic general equilibrium approach to the theory of price level that is often called the fiscal theory of the price level, or FTPL. This way of thinking emphasizes the role of fiscal and monetary policy in determining the risk and return properties of government 
liabilities. It is particularly useful in analyzing proposals for large-scale institutional changes that imply shifts in monetary and fiscal policies. When dollarization is considered from this perspective, some disadvantages are brought to light that may not be so apparent from other points of view.

The so-called fiscal theory of the price level (FTPL) has highlighted that, if government solvency is not guaranteed, monetary policy will not be able to control the price level. In order to ensure stability, fiscal policy has to react sufficiently strongly to a rise in the interest rate in the event of inflationary pressures by increasing the primary surplus. In other words, monetary policy aiming at keeping inflation in check - as the ECD is mandated to behave - has to go hand-in-hand with a fiscal policy obeying a solvency constraint. Once the FTPL is applied to the EMU institutional set-up, however, seemingly different conclusions are drawn. While Sims (1999) considers the Maastricht cum SGP rules insufficient to rule out FTPL's doom scenario, Canzoneri and Diba (2001) conclude that the SGP appears far too strict from the point of view of guaranteeing fiscal solvency. The latter authors, in particular, call for shifting attention from actual to cyclically-adjusted budget balances in assessing the compliance of EMU members with budgetary prudence so as not to hamper fiscal stabilization.

\section{The model}

\subsection{Household and government behavior}

In this section we study a dynamic model, originally due to Obstfeld and Rogoff (1983), that shows how standard monetary models have a continuum of equilibrium time paths for the inflation rate. The model is a Sidrauski - Brock type model with infinite-lived households and money in the utility function. Such models are ones in which it is common for Ricardian equivalence results to be obtained, which makes the fiscalist theory's claim more remarkable than if developed in a model of the overlapping generations type. This type of models was used by several 
authors, such as Woodford (1994, 1995, 2000), Sims (1994, 1996), McCallum (1998), Buiter (1999, 2001), Kocherlakota and Phelan (1999), Chanda and Nolan (2002).

The model is with a representative private agent and a government sector, consisting of a consolidated fiscal authority and central bank.

There is no uncertainty and markets are complete. Time indexed by $t$ is measured in discrete intervals of equal length, normalized to unity.

Households receive an exogenous perishable endowment, $\mathrm{y}_{\mathrm{t}}>0$, each period, consume $c_{t} \geq 0$ and pay net real lump-sum tax $h_{t}$.

The money price of output in period $t$ is $\mathrm{P}_{\mathrm{t}}$. The quantities of money and nominal bonds outstanding at the beginning of period $t$ (and the end of period t-1) are denoted $\mathrm{M}_{t}$, respectively $\mathrm{B}_{t}$. The $i_{t}$ is one-period risk-free nominal interest rate in period $t$, and $r_{t}$ the one-period risk-free real interest rate in period $t$.

The Fisher equation is:

$$
1+r_{t}=\frac{1+i_{t}}{1+\pi_{t}}
$$

where

$$
1+\pi_{t}=\frac{P_{t+1}}{P_{t}}
$$

The single-period household budget constraint is:

$$
P_{t} c_{t}+M_{t+1}+\frac{B_{t+1}}{1+i_{t}} \leq M_{t}+B_{t}+P_{t} y_{t}-P_{t} h_{t}, \forall t \geq 0
$$

We denote:

$$
\mathrm{W}_{\mathrm{t}}=\mathrm{B}_{\mathrm{t}}+\mathrm{M}_{\mathrm{t}}
$$

In order to transform inequalty (2) into an equation, we introduce the slack variable $\mathrm{x}_{\mathrm{t}}$ :

$$
\frac{\mathrm{W}_{\mathrm{t}+1}}{1+\mathrm{i}_{\mathrm{t}}}=\mathrm{W}_{\mathrm{t}}+\mathrm{P}_{\mathrm{t}}\left(\mathrm{y}_{\mathrm{t}}-\mathrm{h}_{\mathrm{t}}-\mathrm{c}_{\mathrm{t}}\right)-\frac{\mathrm{i}_{\mathrm{t}}}{1+\mathrm{i}_{\mathrm{t}}} \mathrm{M}_{\mathrm{t}+1}-\frac{\mathrm{x}_{\mathrm{t}}}{1+\mathrm{i}_{\mathrm{t}}}, \mathrm{x}_{\mathrm{t}} \geq 0, \forall \mathrm{t} \geq 0
$$

In equilibrium, when planned expenditure equals supply, it follows that the economy-wide resource constraint is given by:

$$
\mathrm{c}_{\mathrm{t}}+\mathrm{g}_{\mathrm{t}}=\mathrm{y}_{\mathrm{t}}, \forall \mathrm{t} \geq 0
$$


where we denoted by $g_{t}$ real government expenditure in period t. Equation (4) becomes:

$$
\frac{\mathrm{W}_{\mathrm{t}+1}}{1+\mathrm{i}_{\mathrm{t}}}=\mathrm{W}_{\mathrm{t}}+\mathrm{P}_{\mathrm{t}}\left(\mathrm{g}_{\mathrm{t}}-\mathrm{h}_{\mathrm{t}}\right)-\frac{\mathrm{i}_{\mathrm{t}}}{1+\mathrm{i}_{\mathrm{t}}} \mathrm{M}_{\mathrm{t}+1}-\frac{\mathrm{x}_{\mathrm{t}}}{1+\mathrm{i}_{\mathrm{t}}}, \mathrm{x}_{\mathrm{t}} \geq 0, \forall \mathrm{t} \geq 0
$$

or,

$$
\mathrm{W}_{\mathrm{t}}=\frac{\mathrm{W}_{\mathrm{t}+1}}{1+\mathrm{i}_{\mathrm{t}}}+\mathrm{P}_{\mathrm{t}}\left(\mathrm{h}_{\mathrm{t}}-\mathrm{g}_{\mathrm{t}}\right)+\frac{\mathrm{i}_{\mathrm{t}}}{1+\mathrm{i}_{\mathrm{t}}} \mathrm{M}_{\mathrm{t}+1}+\frac{\mathrm{x}_{\mathrm{t}}}{1+\mathrm{i}_{\mathrm{t}}}
$$

where $h_{t}-g_{t}$ is primary surplus.

The difference equation can be solved forward to yield:

$$
\begin{aligned}
\mathrm{W}_{\mathrm{t}}=\mathrm{B}_{\mathrm{t}}+\mathrm{M}_{\mathrm{t}}= & \prod_{\mathrm{j}=0}^{\mathrm{T}-1}\left(\frac{1}{1+\mathrm{i}_{\mathrm{t}+\mathrm{j}}}\right) \mathrm{W}_{\mathrm{t}+\mathrm{j}}+ \\
& +\sum_{\mathrm{k}=0}^{\mathrm{T}-1}\left(\prod_{j=0}^{\mathrm{k}-1} \frac{1}{1+\mathrm{i}_{\mathrm{t}+\mathrm{j}}}\right)\left[\mathrm{P}_{\mathrm{t}+\mathrm{k}}\left(\mathrm{h}_{\mathrm{t}+\mathrm{k}}-\mathrm{g}_{\mathrm{t}+\mathrm{k}}\right)+\frac{\mathrm{i}_{\mathrm{t}+\mathrm{k}}}{1+\mathrm{i}_{\mathrm{t}+\mathrm{k}}} \mathrm{M}_{\mathrm{t}+\mathrm{k}+\mathrm{l}}+\mathrm{x}_{\mathrm{t}+\mathrm{k}}\right]
\end{aligned}
$$

If the transversality condition:

$$
\lim _{T \rightarrow \infty}\left(\prod_{j=0}^{T-1} \frac{1}{1+i_{t+j}}\right) W_{T+j}=0
$$

is satisfied, then, from (7), it follows:

$$
B_{t}+M_{t}=\sum_{k=0}^{\infty}\left(\prod_{j=0}^{k-1} \frac{1}{1+i_{t+j}}\right)\left[P_{t+k}\left(h_{t+k}-g_{t+k}\right)+\frac{i_{t+k}}{1+i_{t+k}} M_{t+k+1}+x_{t+k}\right]
$$

Relationship (9) represents a solvency condition for the government, or a nonPonzi game condition (Artis and Marcellino - 1998).

From (9), substituting $g_{t}=y_{t}-c_{t}$, we obtain the solvency condition for households:

$$
\begin{aligned}
B_{t}+M_{t}=\sum_{k=0}^{\infty}\left(\prod_{j=0}^{k-1} \frac{1}{1+i_{t+j}}\right)[ & \frac{i_{t+k}}{1+i_{t+k}} M_{t+k+1}- \\
& \left.-P_{t+k}\left(y_{t+k}-h_{t+k}-c_{t+k}\right)+x_{t+k}\right]
\end{aligned}
$$




\subsection{The Optimization Problem}

The representative consumer maximizes the functional J given by (11):

$$
J=\sum_{t=0}^{\infty} \gamma^{t} U\left(c_{t}, \frac{Z_{t}}{P_{t}}\right)
$$

where $\mathrm{U}(\cdot, \cdot)$ denotes the utility, increasing in both arguments, strictly concave and twice differentiable, i.e.:

$$
\mathrm{U}_{\mathrm{c}}^{\prime}(\cdot, \cdot)>0, \mathrm{U}_{\mathrm{z}}^{\prime}(\cdot, \cdot)>0
$$

and the Hessian:

$$
\left(\begin{array}{cc}
\mathrm{U}_{\mathrm{cc}}^{\prime \prime} & \mathrm{U}_{\mathrm{cz}}^{\prime \prime} \\
\mathrm{U}_{\mathrm{zc}}^{\prime \prime} & \mathrm{U}_{\mathrm{zz}}^{\prime \prime}
\end{array}\right)
$$

is negative definite.

Moreover,

$$
\begin{aligned}
& \lim _{c \rightarrow 0} U_{c}^{\prime}\left(c, \frac{Z}{P}\right)=\lim _{z \rightarrow 0} U_{z}^{\prime}\left(c, \frac{Z}{P}\right)=\infty \\
& \lim _{c \rightarrow \infty} U_{c}^{\prime}\left(c, \frac{Z}{P}\right)=0
\end{aligned}
$$

We denoted by:

$$
\mathrm{Z}_{\mathrm{t}}=\mathrm{M}_{\mathrm{t}+1}
$$

and $\gamma$ is the discount factor which equals:

$$
\gamma=\frac{1}{1+\delta} ; \delta>0
$$

where $\delta>0$ is the subjective rate of time preference.

The representative agent maximizes (11) subject to the following dynamic equation:

$$
\mathrm{W}_{\mathrm{t}+1}=\left(1+\mathrm{i}_{\mathrm{t}}\right)\left[\mathrm{W}_{\mathrm{t}}+\mathrm{P}_{\mathrm{t}}\left(\mathrm{y}_{\mathrm{t}}-\mathrm{h}_{\mathrm{t}}-\mathrm{c}_{\mathrm{t}}\right)\right]-\mathrm{i}_{\mathrm{t}} \mathrm{Z}_{\mathrm{t}}-\mathrm{x}_{\mathrm{t}}
$$

$\mathrm{W}_{0}$ given and:

$$
\begin{aligned}
& \mathrm{W}_{\mathrm{t}+1} \geq \mathrm{Z}_{\mathrm{t}} \\
& \mathrm{x}_{\mathrm{t}} \geq 0 \\
& \lim _{\mathrm{T} \rightarrow \infty}\left(\prod_{\mathrm{j}=0}^{\mathrm{T}-1} \frac{1}{1+\mathrm{i}_{\mathrm{t}+\mathrm{j}}}\right) \mathrm{W}_{\mathrm{T}+\mathrm{j}}=0
\end{aligned}
$$


Condition (19) can be written as:

$$
\mathrm{B}_{\mathrm{t}+1}+\mathrm{M}_{\mathrm{t}+1} \geq \mathrm{M}_{\mathrm{t}+1} \text { or } \mathrm{B}_{\mathrm{t}+1} \geq 0
$$

In order to obtain the optimality conditions, we shall apply the Maximum Principle for dynamic systems with discrete variables (Altar, 1976).

The Hamiltonian is:

$$
\begin{aligned}
\mathrm{H}_{\mathrm{t}}=\gamma^{\mathrm{t}} \mathrm{U}\left(\mathrm{c}_{\mathrm{t}}, \frac{\mathrm{Z}_{\mathrm{t}}}{\mathrm{P}_{\mathrm{t}}}\right)+ & \psi_{\mathrm{t}}\left\{\left(1+\mathrm{i}_{\mathrm{t}}\right)\left[\mathrm{W}_{\mathrm{t}}+\mathrm{P}_{\mathrm{t}}\left(\mathrm{y}_{\mathrm{t}}-\mathrm{h}_{\mathrm{t}}-\mathrm{c}_{\mathrm{t}}\right)\right]-\mathrm{i}_{\mathrm{t}} \mathrm{Z}_{\mathrm{t}}-\mathrm{x}_{\mathrm{t}}\right\}+ \\
& +\lambda_{\mathrm{t}}\left\{\left(1+\mathrm{i}_{\mathrm{t}}\right)\left[\mathrm{W}_{\mathrm{t}}+\mathrm{P}_{\mathrm{t}}\left(\mathrm{y}_{\mathrm{t}}-\mathrm{h}_{\mathrm{t}}-\mathrm{c}_{\mathrm{t}}\right)\right]-\left(1+\mathrm{i}_{\mathrm{t}}\right) \mathrm{Z}_{\mathrm{t}}-\mathrm{x}_{\mathrm{t}}\right\}+\mu_{t} x_{t}
\end{aligned}
$$

where we denoted by $\psi_{\mathrm{t}}$ the dual variable, $\lambda_{\mathrm{t}}$ and $\mu_{\mathrm{t}}$ are the Lagrange multipliers corresponding to constraints (19) and (20).

The optimality conditions are:

$$
\left\{\begin{array}{l}
\frac{\partial H_{t}}{\partial c}=0 \\
\frac{\partial H_{t}}{\partial Z}=0 \\
\frac{\partial H_{t}}{\partial x}=0
\end{array}\right.
$$

or

$$
\left\{\begin{array}{l}
\gamma^{t} U_{c}^{\prime}\left(c_{t}, \frac{Z_{t}}{P_{t}}\right)=\left(1+i_{t}\right) P_{t}\left(\psi_{t}+\lambda_{t}\right) \\
\gamma^{t} U_{z}^{\prime}\left(c_{t}, \frac{Z_{t}}{P_{t}}\right) \cdot \frac{1}{P_{t}}=i_{t} \psi_{t}+\left(1+i_{t}\right) \lambda_{t} \\
\psi_{t}=\mu_{t}
\end{array}\right.
$$

The dynamic equation of the dual variable $\psi_{\mathrm{t}}$ is: 


$$
\psi_{\mathrm{t}-1}=\frac{\partial \mathrm{H}_{\mathrm{t}}}{\partial \mathrm{W}_{\mathrm{t}}}
$$

or

$$
\psi_{\mathrm{t}-1}=\left(1+\mathrm{i}_{\mathrm{t}}\right) \psi_{\mathrm{t}}+\left(1+\mathrm{i}_{\mathrm{t}}\right) \lambda_{\mathrm{t}}
$$

Concerning the Lagrange multipliers, the Maximum Principle provides the following information:

$$
\begin{array}{ll}
\lambda_{\mathrm{t}} \geq 0 ; & \lambda_{\mathrm{t}}\left[\mathrm{W}_{\mathrm{t}+1}-\mathrm{Z}_{\mathrm{t}}\right]=0 \\
\mu_{\mathrm{t}} \geq 0 ; & \mu_{\mathrm{t}} \cdot \mathrm{x}_{\mathrm{t}}=0
\end{array}
$$

From the second condition (29) we can see that $x_{t}>0$ implies $\mu_{t}=0$.

In this case, from the third relation (24) it would follow $\Psi_{t}=\mu_{t}=0$, which would make the problem senseless. It follows that $\mathrm{x}_{\mathrm{t}}=0, \forall t \geq 0$, hence the consumer budget constraint (2) on the optimal trajectory is satisfied as an equality.

From the first relation (27) it follows that $\lambda_{t}>0$ implies $\mathrm{W}_{\mathrm{t}+1}-\mathrm{Z}_{\mathrm{t}}=0$, i.e. $B_{t+1}=0$. In other words, if $\lambda_{t}>0$, then the agent will not buy bonds in the given period.

We perform the substitutions:

$$
\mathrm{q}_{\mathrm{t}}=\frac{\psi_{\mathrm{t}}}{\gamma^{\mathrm{t}}} ; \alpha_{\mathrm{t}}=\frac{\lambda_{\mathrm{t}}}{\gamma^{\mathrm{t}}}
$$

In this case, the optimality conditions (24) become:

$$
\left\{\begin{array}{l}
U_{c}^{\prime}\left(c_{t}, \frac{Z_{t}}{P_{t}}\right)=\left(1+i_{t}\right) P_{t}\left(q_{t}+\alpha_{t}\right) \\
U_{c}^{\prime}\left(c_{t}, \frac{Z_{t}}{P_{t}}\right)=P_{t} i_{t} q_{t}+\left(1+i_{t}\right) \alpha_{t}
\end{array}\right.
$$

and the dynamic equation becomes:

$$
q_{t-1}=\gamma\left(1+i_{t}\right)\left(q_{t}+\alpha_{t}\right)
$$

or 


$$
q_{t}=\frac{1}{\gamma\left(1+i_{t}\right)} q_{t-1}-\alpha_{t}
$$

\subsection{Qualitative analysis of optimal trajectories}

In what follows, to facilitate the analysis, we assume that the utility function is separable in both arguments:

$$
U\left(c_{t}, \frac{Z_{t}}{P_{t}}\right)=V\left(c_{t}\right)+\varphi\left(\frac{Z_{t}}{P_{t}}\right)
$$

In this case, the optimality conditions (29) become:

$$
\begin{aligned}
& V^{\prime}\left(c_{t}\right)=\left(1+i_{t}\right) P_{t}\left(q_{t}+\alpha_{t}\right) \\
& \varphi^{\prime}\left(\frac{Z_{t}}{P_{t}}\right)=i_{t} P_{t} q_{t}+P_{t}\left(1+i_{t}\right) \alpha_{t}
\end{aligned}
$$

If $\mathrm{B}_{\mathrm{t}+1}>0$, in other words, if the agent buys bonds the $\mathrm{n}^{\text {th }}$ multiplier $\alpha_{\mathrm{t}}$ vanishes and the relations (30) - (33) become:

$$
\begin{aligned}
& q_{t}=\frac{1}{\gamma\left(1+i_{t}\right)} q_{t-1} \\
& V^{\prime}\left(c_{t}\right)=\left(1+i_{t}\right) P_{t} q_{t} \\
& \varphi^{\prime}\left(\frac{Z_{t}}{P_{t}}\right)=P_{t} i_{t} q_{t}
\end{aligned}
$$

Writing the optimality condition (35) for two consecutive periods, we have:

$$
\begin{aligned}
& V^{\prime}\left(c_{t}\right)=\left(1+i_{t}\right) P_{t} q_{t} \\
& V^{\prime}\left(c_{t-1}\right)=\left(1+i_{t-1}\right) P_{t-1} q_{t-1}
\end{aligned}
$$

and, taking into account relation (34), it follows:

$$
\frac{V^{\prime}\left(c_{t}\right)}{V^{\prime}\left(c_{t-1}\right)}=\frac{1}{\gamma} \frac{1}{1+i_{t-1}} \frac{P_{t}}{P_{t-1}}
$$


Denoting

$$
1+\pi_{t-1}=\frac{P_{t}}{P_{t-1}}
$$

where $\pi_{\mathrm{t}-1}$ stands for inflation rate, relation (37) becomes:

$$
\frac{\mathrm{V}^{\prime}\left(\mathrm{c}_{\mathrm{t}}\right)}{\mathrm{V}^{\prime}\left(\mathrm{c}_{\mathrm{t}-1}\right)}=\frac{1+\delta}{1+\mathrm{r}_{\mathrm{t}-1}}
$$

where $\delta$ is the subjective rate of preference and $\mathrm{r}$ is the risk-free real interest rate. Relation (39) allows to identify the following situations:

a) if $\mathrm{r}_{\mathrm{t}-1}=\delta$, then $\mathrm{c}_{\mathrm{t}}=\mathrm{c}_{\mathrm{t}-1}$

b) if $r_{t-1}>\delta$, then $c_{t}>c_{t-1}$

c) if $\mathrm{r}_{\mathrm{t}-1}<\delta$, then $\mathrm{c}_{\mathrm{t}}<\mathrm{c}_{\mathrm{t}-1}$

Therefore, depending on the evolution of inflation and of the risk-free nominal interest rate, consumption can be constant, increasing or decreasing.

To identify the evolution of the demand for money, we use optimality condition (36). We obtain:

$$
\frac{\varphi^{\prime}\left(\frac{Z_{t}}{P_{t}}\right)}{\varphi^{\prime}\left(\frac{Z_{t-1}}{P_{t-1}}\right)}=\frac{P_{t}}{P_{t-1}} \frac{i_{t}}{i_{t-1}} \frac{1}{\gamma\left(1+i_{t}\right)}
$$

or

$$
\frac{\varphi^{\prime}\left(\frac{Z_{t}}{P_{t}}\right)}{\varphi^{\prime}\left(\frac{Z_{t-1}}{P_{t-1}}\right)}=\frac{P_{t}}{P_{t-1}} \cdot \frac{i_{t}}{i_{t-1}} \cdot \frac{1+\delta}{1+i_{t}}
$$

If we admit that:

a) inflation is constant: $\frac{P_{t}}{P_{t-1}}=1+\pi$

b) $\mathrm{i}_{\mathrm{t}}=\mathrm{i}_{\mathrm{t}-1}$ 
c) $\delta=\mathrm{r}=\frac{1+\mathrm{i}}{1+\pi}$

then, from (41), we obtain:

$$
\frac{\varphi^{\prime}\left(\frac{Z_{t}}{P_{t}}\right)}{\varphi^{\prime}\left(\frac{Z_{t-1}}{P_{t-1}}\right)}=1
$$

or

$$
\frac{Z_{t}}{P_{t}}=\frac{Z_{t-1}}{P_{t-1}}
$$

and

$$
\frac{\mathrm{M}_{\mathrm{t}+1}}{\mathrm{M}_{\mathrm{t}}}=\frac{\mathrm{P}_{\mathrm{t}}}{\mathrm{P}_{\mathrm{t}-1}}=1+\pi .
$$

Thus, under assumptions (a), (b), (c), the demand for money growths with the same rate as inflation:

$$
\mathrm{M}_{\mathrm{t}+1}=(1+\pi) \cdot \mathrm{M}_{\mathrm{t}}
$$

\subsection{Transversality conditions}

For the optimal trajectories, the Maximum Principle provides the transversality condition:

$$
\lim _{\mathrm{T} \rightarrow \infty} \psi_{\mathrm{T}} \mathrm{W}_{\mathrm{T}}=0
$$

Taking into account the substitution (28), relation (44) becomes:

$$
\lim _{\mathrm{T} \rightarrow \infty} \gamma^{\mathrm{T}} \mathrm{q}_{\mathrm{T}} \mathrm{W}_{\mathrm{T}}=0
$$

Since $\mathrm{W}_{\mathrm{T}}=\mathrm{B}_{\mathrm{T}}+\mathrm{M}_{\mathrm{T}}$ with $\mathrm{B}_{\mathrm{T}} \geq 0$ and $\mathrm{M}_{\mathrm{T}} \geq 0$, the transversality condition (45) becomes:

$$
\lim _{\mathrm{T} \rightarrow \infty} \gamma^{\mathrm{T}} \mathrm{q}_{\mathrm{T}} \mathrm{B}_{\mathrm{T}}=0
$$




$$
\lim _{\mathrm{T} \rightarrow \infty} \gamma^{\mathrm{T}} \mathrm{q}_{\mathrm{T}} \mathrm{M}_{\mathrm{T}}=0
$$

From the dynamic equation (34) for the dual variable, we obtain:

$$
\mathrm{q}_{\mathrm{T}}=\frac{1}{\gamma^{\mathrm{T}}} \prod_{\mathrm{k}=1}^{\mathrm{T}}\left(\frac{1}{1+\mathrm{i}_{\mathrm{k}}}\right) \mathrm{q}_{0}
$$

Taking into account relation (48), the transversality conditions can be written as:

$$
\begin{aligned}
& \lim _{\mathrm{T} \rightarrow \infty} \prod_{\mathrm{k}=1}^{\mathrm{T}}\left(\frac{1}{1+\mathrm{i}_{\mathrm{k}}}\right) \mathrm{B}_{\mathrm{T}}=0 \\
& \lim _{\mathrm{T} \rightarrow \infty} \prod_{\mathrm{k}=1}^{\mathrm{T}}\left(\frac{1}{1+\mathrm{i}_{\mathrm{k}}}\right) \mathrm{M}_{\mathrm{T}}=0
\end{aligned}
$$

Remark: Relation (20), given earlier, follows from (46') and (47').

If the nominal risk-free interest rate is constant:

$$
\mathrm{i}_{\mathrm{k}}=\mathrm{i}_{\mathrm{k}+1}=\mathrm{i}, \forall \mathrm{k} \geq 0
$$

then the transversality conditions become:

$$
\begin{aligned}
& \lim _{\mathrm{T} \rightarrow \infty}\left(\frac{1}{1+i}\right)^{\mathrm{T}} \mathrm{B}_{\mathrm{T}}=0 \\
& \lim _{\mathrm{T} \rightarrow \infty}\left(\frac{1}{1+\mathrm{i}}\right)^{\mathrm{T}} \mathrm{M}_{\mathrm{T}}=0
\end{aligned}
$$

This means that the sequences $\left\{\mathrm{B}_{\mathrm{t}}\right\}_{\mathrm{t} \in \mathrm{N}}$ and $\left\{\left\{\mathrm{M}_{\mathrm{t}}\right\}_{\mathrm{t} \in \mathrm{N}}\right.$ should increase slower than the sequence $\left\{\left(\frac{1}{1+\mathrm{i}}\right)^{\mathrm{t}}\right\}_{\mathrm{t} \in \mathrm{N}}$ 


\subsection{The case of Bernoulli type utility functions}

In order to have a convenient parametric example, we assume that the utility functions $\mathrm{V}($.$) and \varphi($.$) are of Bernoulli type, i.e. their elasticity of marginal utility is$ constant.

Let us suppose that :

$$
\begin{aligned}
& \mathrm{V}(\mathrm{c})=\frac{1}{1-\sigma} \mathrm{c}^{1-\sigma} \\
& \varphi\left(\frac{\mathrm{Z}_{\mathrm{t}}}{\mathrm{P}_{\mathrm{t}}}\right)=\frac{1}{1-\theta}\left(\frac{\mathrm{Z}_{\mathrm{t}}}{\mathrm{P}_{\mathrm{t}}}\right)^{1-\theta}
\end{aligned}
$$

where $\sigma \in(0,1)$.

In this case, condition (39) deduced from the optimality conditions becomes:

$$
c_{t}=\left(\frac{1+r_{t-1}}{1+\delta}\right)^{\frac{1}{\sigma}} c_{t-1}
$$

Relation (51) represents a dynamic equation for the control variable $c_{t}$.

As a matter of fact, it is known that the Bernoulli type utility functions are the only utility functions allowing the inference of a dynamic equation for the control variable.

Relation (51) shows that, in order to know the dynamics of optimal consumption, it is sufficient to know the evolution of the risk-free real interest rate, as well as the initial value $\mathrm{c}_{0}$ of consumption.

From (51) it follows:

$$
\mathrm{c}_{\mathrm{t}}=\prod_{\mathrm{k}=0}^{\mathrm{t}-1}\left(\frac{1+\mathrm{r}_{\mathrm{k}}}{1+\delta}\right)^{\frac{1}{\sigma}} \mathrm{c}_{0}
$$

or

$$
\mathrm{c}_{\mathrm{t}+\mathrm{T}}=\prod_{\mathrm{k}=0}^{\mathrm{T}}\left(\frac{1+\mathrm{r}_{\mathrm{t}+\mathrm{k}}}{1+\delta}\right)^{\frac{1}{\sigma}} \mathrm{c}_{\mathrm{t}}
$$

As concerns the demand for money, from relations (35) and (36) we obtain:

$$
\frac{\varphi^{\prime}\left(\frac{Z_{t}}{P_{t}}\right)}{V^{\prime}\left(c_{t}\right)}=\frac{i_{t}}{1+i_{t}}
$$

Substituting the expressions of the derivatives, we obtain 


$$
\frac{\mathrm{Z}_{\mathrm{t}}}{\mathrm{P}_{\mathrm{t}}}=\left(\frac{1+\mathrm{i}_{\mathrm{t}}}{\mathrm{i}_{\mathrm{t}}}\right)^{\frac{1}{\theta}} \mathrm{c}_{\mathrm{t}}^{\frac{\sigma}{\theta}}
$$

Taking into account that $Z_{t}=M_{t+1}$, relation (54) can be written as:

$$
M_{t+1}=P_{t}\left(\frac{1+i_{t}}{i_{t}}\right)^{\frac{1}{\theta}} c_{t}^{\frac{\sigma}{\theta}}
$$

It can be seen that the demand for money $\mathrm{M}_{t+1}$ increases as $\mathrm{P}_{t}$ and $\mathrm{C}_{t}$ increase and decreases as $i_{t}$ increases, which is consistent with the properties that a function of money demand should have.

We denote:

$$
\mathrm{m}_{\mathrm{t}+1}=\frac{\mathrm{M}_{\mathrm{t}+1}}{\mathrm{P}_{\mathrm{t}+1}}
$$

From (55), it follows:

$$
\mathrm{m}_{\mathrm{t}+1}=\frac{1}{1+\pi_{\mathrm{t}}}\left(\frac{1+\mathrm{i}_{\mathrm{t}}}{\mathrm{i}_{\mathrm{t}}}\right)^{\frac{1}{\theta}} \mathrm{c}_{\mathrm{t}}^{\frac{\sigma}{\theta}}
$$

It can be seen that $\mathrm{m}_{\mathrm{t}+1}$ decreases as the inflation rate $\pi_{\mathrm{t}}$ increases.

If the nominal interest rate and inflation rate are constant and, moreover,

$$
1+\mathrm{r}=\frac{1+\mathrm{i}}{1+\pi}=1+\delta
$$

then, from (51), it follows that consumption is constant, i.e.

$$
\mathrm{c}_{\mathrm{t}}=\mathrm{c}_{\mathrm{t}-1}, \forall \mathrm{t}
$$

In this case, the real demand for money will also be constant:

$$
\mathrm{m}=\frac{1}{1+\pi}\left(\frac{1+\mathrm{i}}{\mathrm{i}}\right)^{\frac{1}{\theta}} \mathrm{c}^{\frac{\sigma}{\theta}}
$$

From (58) we obtain the nominal interest rate:

$$
\mathrm{i}=(1+\delta)(1+\pi)-1
$$

and formula (60) becomes 


$$
\mathrm{m}=\frac{1}{1+\pi}\left(\frac{1}{1-\frac{1}{(1+\delta)(1+\pi)}}\right)^{\frac{1}{\theta}} \mathrm{c}^{\frac{\sigma}{\theta}}
$$

Therefore, under the above assumption, if the Central Bank decides about the magnitude of the inflation rate $\pi$, the magnitude of the nominal interest rate will be given by (61), and the real demand for money will be given by (62).

\section{Compatibility between Monetary and Fiscal Policy. Fiscal Solvency.}

The interaction between monetary and fiscal policy remains a topic of intense interest to macroeconomists.

In this section, we adopt several simple assumptions concerning monetary and fiscal policy, in order to see how the Fiscal Solvency conditions are satisfied (these are, in fact, transversality conditions (46') and (47')) ).

As it concerns the monetary policy of the Central Bank, we assume that the following conditions are satisfied:

a). constant inflation rate;

b). constant nominal interest rate.

Moreover, we assume that the nominal interest rate is that given by the formula (61), which implies constant consumption.

For the sake of simplicity, we assume that the exogenous endowment $y$ is the same in each period:

$$
\mathrm{y}_{\mathrm{t}-1}=\mathrm{y}_{\mathrm{t}}=\mathrm{y} \quad \forall \mathrm{t} \geq 0
$$

Since the real government expenditure in each period is

$$
\mathrm{g}_{\mathrm{t}}=\mathrm{y}_{\mathrm{t}}-\mathrm{c}_{\mathrm{t}}
$$

it follows that this is also constant, hence

$$
\mathrm{g}_{\mathrm{t}-1}=\mathrm{g}_{\mathrm{t}}=\mathrm{g} \quad \forall \mathrm{t} \geq 0
$$


Dividing by $\mathrm{P}_{\mathrm{t}}$ the budget equation (2) of the household, we obtain

$$
c_{t}+\frac{M_{t+1}}{P_{t+1}} \frac{P_{t+1}}{P_{t}}+\frac{B_{t+1}}{P_{t+1}} \frac{P_{t+1}}{P_{t}} \frac{1}{1+i}=\frac{M_{t}}{P_{t}}+\frac{B_{t}}{P_{t}}+y-h_{t}
$$

Denoting

$$
\mathrm{b}_{\mathrm{t}}=\frac{\mathrm{B}_{\mathrm{t}}}{\mathrm{P}_{\mathrm{t}}} ; \mathrm{m}_{\mathrm{t}}=\frac{\mathrm{M}_{\mathrm{t}}}{\mathrm{P}_{\mathrm{t}}}
$$

and taking into account that $\mathrm{y}-\mathrm{c}=\mathrm{g}$, relation (66) can be written as

$$
\frac{b_{t+1}}{1+r}=b_{t}+\left(g-h_{t}\right)-\left[m_{t+1}(1+\pi)-m_{t}\right]
$$

Taking into account the assumptions concerning inflation rate and nominal interest rate, it follows that the real demand for money is also constant:

$$
\mathrm{m}_{\mathrm{t}+1}=\mathrm{m}_{\mathrm{t}}=\mathrm{m} \quad \forall \mathrm{t} \geq 0
$$

its magnitude being given by relation (62).

Formula (67) can be written as:

$$
\frac{b_{t+1}}{1+r}=b_{t}+\left(g-h_{t}\right)-\pi m
$$

or

$$
\frac{b_{t+1}}{1+r}=b_{t}-S_{t}
$$

where we denoted by $S_{t}$ primary surplus inclusive of seignorage;

$$
\mathrm{S}_{\mathrm{t}}=\mathrm{h}_{\mathrm{t}}+\pi \mathrm{m}-\mathrm{g}
$$

As it concerns fiscal policy, we assume a constant lump-sum tax:

$$
\mathrm{h}_{\mathrm{t}}=\mathrm{h} \quad \forall \mathrm{t} \geq 0
$$

In this case, the primary surplus inclusive of seignorage is constant :

$$
\mathrm{S}_{\mathrm{t}}=\mathrm{S} \quad \forall \mathrm{t} \geq 0
$$

and equation (69') becomes:

$$
\frac{b_{t+1}}{1+r}=b_{t}-S
$$

or

$$
b_{t+1}=(1+r) b_{t}-(1+r) S
$$

The solution of the difference equation (73') is 


$$
\mathrm{b}_{\mathrm{T}}=(1+\mathrm{r})^{\mathrm{T}} \mathrm{b}_{0}-\frac{1+\mathrm{r}}{\mathrm{r}}\left[(1+\mathrm{r})^{\mathrm{T}}-1\right)
$$

where from:

$$
\frac{b_{T}}{(1+r)^{\mathrm{T}}}=b_{0}-\frac{1+r}{r}\left[1-\frac{1}{(1+r)^{\mathrm{T}}}\right] \mathrm{S}
$$

Taking into account that

$$
\begin{aligned}
& \mathrm{b}_{\mathrm{T}}=\frac{\mathrm{B}_{\mathrm{T}}}{\mathrm{P}_{\mathrm{T}}} \\
& \mathrm{P}_{\mathrm{T}}=(1+\pi)^{\mathrm{T}} \mathrm{P}_{0}
\end{aligned}
$$

we obtain from (75)

$$
\frac{\mathrm{B}_{\mathrm{T}}}{(1+\mathrm{i})^{\mathrm{T}}}=\frac{\mathrm{B}_{0}}{\mathrm{P}_{0}}-\frac{1+\mathrm{r}}{\mathrm{r}}\left[1-\left(\frac{1}{1+\mathrm{r}}\right)^{\mathrm{T}}\right] \mathrm{S}
$$

and

$$
\lim _{\mathrm{T} \rightarrow \infty} \frac{\mathrm{B}_{\mathrm{T}}}{(1+\mathrm{i})^{\mathrm{T}}}=\mathrm{b}_{0}-\frac{1+\mathrm{r}}{\mathrm{r}} \mathrm{S}
$$

The transversality conditions will be satisfied only if

$$
\mathrm{S}=\frac{\mathrm{r}}{1+\mathrm{r}} \mathrm{b}_{0}
$$

i.e if the magnitude of the lump-sum tax is

$$
\mathrm{h}=\mathrm{g}-\pi \mathrm{m}+\frac{\mathrm{r}}{1+\mathrm{r}} \mathrm{b}_{0}
$$

We remark that if the value of the tax is given by (80), then from the dynamic equation (73), we obtain

$$
\mathrm{b}_{0}=\mathrm{b}_{1}=\mathrm{b}_{2}=\ldots=\mathrm{b}_{\mathrm{t}}, \forall \mathrm{t} \in \mathrm{N}
$$

i.e. the real debt is constant, and the nominal debt increases at the inflation rate:

$$
\mathrm{B}_{\mathrm{T}}=(1+\pi)^{\mathrm{T}} \mathrm{B}_{0}
$$

From the budget constraint equation for $\mathrm{t}=0$, we have

$$
\mathrm{m}=\mathrm{m}_{0}
$$

where $\mathrm{m}_{0}=\frac{\mathrm{M}_{0}}{\mathrm{P}_{0}}$ is given. 
Taking into account the relation (62) it follows that:

$$
\mathbf{c}=(1+\pi)^{\frac{\theta}{\sigma}}\left[\frac{(1+\delta)(1+\pi)-1}{(1+\delta)(1+\pi)}\right]^{\frac{1}{\sigma}} \mathrm{m}_{0}^{\frac{\theta}{\sigma}}
$$

For the considered hypotheses the optimal solution is as follows:

$$
\mathrm{c}_{0}=\mathrm{c}_{1}=\ldots=\mathrm{c}_{\mathrm{t}}=\mathrm{c}, \forall \mathrm{t} \geq 0
$$

where $\mathrm{c}$ is given in (84)

$$
\mathrm{m}_{0}=\mathrm{m}_{1}=\ldots=\mathrm{m}_{\mathrm{t}}=\mathrm{m}, \forall \mathrm{t} \geq 0
$$

It follows that the nominal money demand is given by:

$$
\mathrm{M}_{\mathrm{t}}=(1+\pi)^{\mathrm{t}} \mathrm{M}_{0}, \forall \mathrm{t} \geq 0
$$

Taking into account (11), (31) and (50) the objective function becomes:

$$
J=\sum_{t=0}^{\infty} \gamma^{t}\left[\frac{1}{1-\sigma} c_{t}^{1-\sigma}+\frac{1}{1-\theta}\left(\frac{M_{t+1}}{P_{t}}\right)^{1-\theta}\right]
$$

Using the optimal solution given by (85) and (86) we have:

$$
\mathrm{J}=\frac{1+\delta}{\delta} \mathrm{c}+\frac{1+\delta}{\delta-\pi}\left(\frac{\mathrm{M}_{0}}{\mathrm{P}_{0}}\right)
$$

Considering (84) it follows

$$
\mathrm{J}(\pi)=\frac{1+\delta}{\delta}(1+\pi)^{\frac{\theta}{\sigma}}\left[\frac{(1+\delta)(1+\pi)-1}{(1+\delta)(1+\pi)}\right]^{\frac{1}{\sigma}} \mathrm{m}_{\mathrm{o}}^{\frac{\theta}{\sigma}}+\frac{1+\delta}{\delta-\pi} \mathrm{m}_{0}
$$

One can observe that the objective function depends on the inflation rate $\pi$, set by the Central Bank, as well as on the initial real money balances.

\section{Conclusions}

We studied in this paper a discrete time economic growth model, having elements of monetary and fiscal policy. For the case when the utility function of the household is of Bernoulli type, we obtained the dynamic equation of consumption. The dynamics depend on the nominal interest rate and on the inflation rate. If the real interest rate coincides with the subjective discount rate, then optimal consumption is constant on the whole horizon. The real demand for money is also constant. 
Assuming a monetary policy rule with constant nominal interest rate and constant inflation rate, we inferred the fiscal policy rules compatible with this one.

Fiscal solvency is an important concern in the design of macroeconomic policy in EMU. Within the model, fiscal solvency conditions practically coincides with the transversality conditions provided by the Maximum Principle.

There are a number of directions in which our analysis can be developed. Obvious extensions include the incorporation of distortionary taxation and of "useful" government expenditure and the way in which these contribute to the "welfare" of the agent.

\section{References}

Artis, M. J. and Buti, M. (2000) - "'Close to Balance or In Surplus" - A Policy Maker's Guide to the Implementation of the Stability and Growth Pact'. Journal of Common Market Studies, vol. 38, No. 4, pp. 563-92

Artis, M. J. and Buti, M. (2001) - 'Setting Medium Term Fiscal Targets in EMU'. in Brunila et al. (eds), pp. 185-203

Barro, R. J. (1974), “Are government Bonds Net Wealth?”, Journal of Political Economy, vol 82, no 6, pp 1095-1117

Barro, R. J. (1979), “On the Determination of the Public Debt", Journal of Political Economy, vol 87, no 5, pp 940-71

Barro, R. J. (1981), “Output Effects of Government Purchases”, Journal of Political Economy, vol 89, no. 6, pp. 1086-1121

Barro, R.J., (1990), "Government Spending in a Simple Model of Endogenous Growth", Journal of Political Economy 98, S103-S125

Barro, R.J., (1995), "Infation in Economic Growth", Bank of England Quarterly Bulletin May, 166-176

Beetsma, R. (2001) - 'Does EMU Need a Stability Pact?'. In Brunila et al. (eds), pp. $23-52$

Beetsma, R. and Uhlig, H. (1999) - 'An Analysis of the Stability and Growth Pact'. Economic Journal, Vol. 109, No. 4, pp. 546-71 
Beetsma, R., Debrun, X. and Klaassen, F. (2001) - 'Is Fiscal Policy Co-ordination in EMU Desirable?'. Paper presented at the Economic Council of Sweden Conference 'Macroeconomic Policy Co-ordination in the EU: How Far Should It Go?', Stockholm, 28 May

Blanchard, O. (2000) - 'Commentary: Fiscal Policy in an Era of Surpluses: Economic and Financial Implications'. Federal Reserve Bank of New York - Economic Policy Review, Vol. 6, No. 1, pp. 69-74

Blanchard, O. J. (1985), "Debts, Deficits and Finite Horizons", Journal of Political Economy, 93, pp. 223-247

Bohn, H. (1995), "The Sustainability of Government deficits in a Stochastic Economy", Journal of Money Credit and banking, 27, no.1, pp 257-71

Bohn, H. (1998), “The Behavior of U.S. Public Debt and Deficits”, Quarterly Journal of Economics, vol 113, no 3, pp 949-63

Brock, W. A. (1995), “A Simple Perfect Foresight Monetary Model”, Journal of Monetary Economics, vol 1, pp 133-50

Buiter, W. H. (1988), "Death, Birth, Productivity Growth and Debt Neutrality", The Economic Journal, vol 98, no 391, pp. 279-293

Buiter, W. H. (1998), “The Young Person's Guide to Neutrality, Price Level Indeterminacy, Interest Rate Pegs and Fiscal Theories of the Price Level", NBER Working Paper, no 6396, Cambridge, Massachusetts

Bullard, J. and J. Keating, (1995), "The Long-Run Relationship Between Inflation and Output in Postwar Economies", Journal of Monetary Economics 36 (3), 477496

Buti, M. and Martinot, B. (2000) - 'Open Issues in the Implementation of the Stability and Growth Pact'. National Institute Economic Review, No. 174, pp. 92-104

Buti, M., Roeger, W. and in't Veld, J. (2001) - 'Monetary and Fiscal Policy Interactions under a Stability Pact'. EUI Working Papers, ECO No. 8

Calvo, G.A., (1983), "Staggered Prices in a Utility Maximizing Framework", Journal of Monetary Economics, 12,3,983-998

Calvo, G.A., (1985), "Macroeconomic Implications of the Government Budget Constraint: Some Basic Considerations", Journal of Monetary Economics, $15,95-112$

Canzoneri, M. B. and Diba, B. T. (2001) - 'The Stability anf Growth Pact: A Delicate Balance or an Albatross?'. In Brunila et al. (eds), pp. 53-74 
Canzoneri, M.B., C. Nolan and A. Yates, (1997), "Mechanisms for Achieving Monetary Stability: Inflation Targeting versus the ERM", Journal of Money, Credit and Banking, 29(1),44-60

Canzoneri, M.B., R.E. Cumby and B.T. Diba, (2001), "Is the Price Level Determined by the Needs of the Fiscal Solvency?", American Economic Review, forthcoming

Chadha, J. S., and C. Nolan (2002a), "Inflation versus Price-Level targeting in a New Keynesian Macro-model”, The Manchester School

Chadha, J. S., and C. Nolan (2002b), "Optimal Simple Rules for Conduct of Monetary and Fiscal Policy". Working paper available at http://www.dur.ac.uk/charles.nolan/index.html

Chadha, J. S., N. Janssen and C. Nolan (2001), "Productivity and Preferences in a Small Open Economy", The Manchester School, vol 69, pp 57-80

Chari, V.V., L. Jones, and R. Manuelli, (1995), “The Growth Effects and of Monetary Policy”, Quarterly Review, Federal Reserve Bank of Minneapolis, Fall, 18-32

Christiano, L. J., and T. J. Fitzgerald (2000), "Understanding the Fiscal Theory of the Price Level", Federal Reserve Bank of Cleveland Economic Review, vol 36, no 2, pp 1-37

Clarida, R., Gali, J. and Gertler, M. (1999) - 'The Science of Monetary Policy: A New Keynesian Perspective'. Journal of Economic Literature, Vol. XXXVII, pp. 1661-707

Dixit, A. and Lambertini, L. (2000a) - 'Symbiosis of Monetary and Fiscal Policies in a Monetary Union’. Working Paper, Princeton/UCLA, March

Dixit, A. and Lambertini, L. (2000b) - 'Fiscal Discretion Destroys Monetary Commitment'. Working Paper, Princeton/UCLA, August

Dixit, A. and Lambertini, L. (2000c) - 'Monetary-Fiscal Policy Interactions and Commitment Versus Discretion in a Monetary Union'. Working Paper, Princeton/UCLA, August

Eichengreen, B. and Wyplosz, C. (1998) - 'Stability Pact - More than a Minor Nuisance?’. Economic Policy, No. 26, pp. 65-114

Erceg, C., D. Henderson and A. Levin, (2000), "Optimal Monetary Policy with Staggered Wage and Price Contracts", Journal of Monetary Economics 46, 281-313

Hamilton, J.D., and M.A. Flavin, (1986), "On the Limitation of Government Borrowing: A Framework for Empirical Testing”, American Economic Review $76,4,808-819$ 
King, R.G. and R.Levine, (1993), "Finance, Entrepreneurship, and Growth: Theory and Evidence", Journal of Monetary Economics 32, 513-542

King, R.G. and S. Rebelo, (1990), "Public Policy and Economic Growth: Developing Neoclassical Implications", Journal of Political Economy 98, S126-S150

Kocherlakota, N. and C. Phelan, (1999), "Explaining the Fiscal Theory of the Price Level”, Quarterly Review, Federal Reserve Bank of Minneapolis 23,4,14-23

Leeper, E., (1991), “Equilibria Under 'Active' and 'Passive' Monetary Policies", Journal of Monetary Economics, 27,1,129-147

Leith, Campbell, and Wren-Lewis, Simon (2000) 'Interactions between monetary and fiscal policy rules`. The Economic Journal, 110 March

Lucas, R.E., Jr., (1988), “On the Mechanics of Economic Development”, Journal of Monetary Economics 22, 3-42

Lucas, R.E., Jr., (1996), "Noble Lecture: Monetary Neutrality”, Journal of Political Economy, 104,4,661-682

McCallum, B.T.,(1984), "Are Bond- financed Deficits Inflationary? A Ricardian Analysis",The Journal of Political Economy, Volume 92, Issue1,123-135

McCallum, B.T., (2001), "Indeterminacy Bubbles and the Fiscal Theory of PriceLevel Determination”, Journal of Monetary Economics, 47,1,19-30

Obstfeld, M. and K. Rogoff, (1983), "Speculative Hyperinflations in Maximizing Models: Can We Rule Them Out?", Journal of Monetary Economics, 91,4,675-687

Palivos, T. and C.K. Yip, (1995), "Government Expenditure Financing in an Endogenous Growth Model", Journal of Money, Credit and Banking 27, $1159-1178$

Rebelo, S., (1991), "Long Run Policy and Long Run Growth", Journal of Political Economy 99, 500-521

Romer, P.M., (1996), "Increasing Returns and Long-Run Growth", Journal of Political Economy 94, 1002-1037

Sargent, T. J. and N. Wallace(1981) "Some Unpleasant Monetarist Arithmetic", Federal Reserve Bank of Minneapolis Quaterly Review, vol 5, no3, pp1-17

Sims, C., (1994), "A Simple Model for the Study of the Price Level and the Interaction of Monetary and Fiscal Policy", Economic Theory 4,3,381-399

Sims, C., (1999), "The Precarious Fiscal Foundations of EMU", Der Economist $147,4,415-436$ 
Turnovsky, S.J., (1992), “Alternative Forms of Government Expenditures Financing: A Comparative Welfare Analysis", Economica 59, 23-52

van Aarle, B., Engwerda, J. C., Plasmans, J. E. J. and Weeren, A. (2000) - 'Monetary and Fiscal Policy Design under EMU: A Dynamic Game Approach'. CESifo Working Paper No. 262

Van der Ploeg, F. and G. Alogoskofis, (1994), "Money and Endogenous Growth", Journal of Money, Credit and Banking 26, 771-791

Woodford, M. (1995) - 'Price Level Determinacy Without Control of a Monetary Aggregate'. Carnegie-Rochester Conference Series on Public Policy, Vol. 43, pp. $1-46$

Woodford, M., (2001), "Fiscal Requirements for Price Stability", Journal of Money, Credit and Banking 33,3,669-728

Wyplosz, C. (1999) - 'Economic Policy Co-ordination in EMU: Strategies and Institutions'. ZEI Policy Paper, B11, Centre for European Integration Studies, University of Bonn 